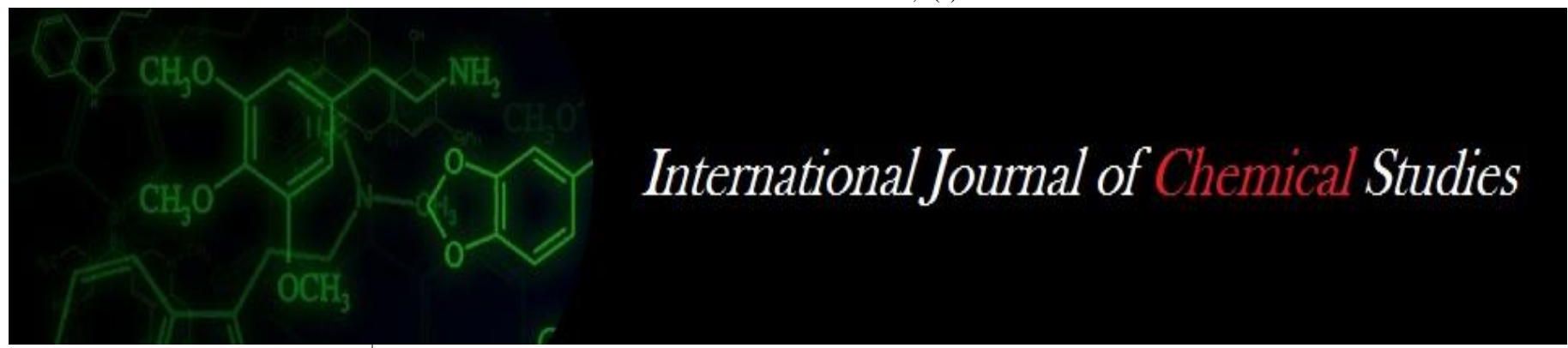

P-ISSN: 2349-8528

E-ISSN: 2321-4902

www.chemijournal.com

IJCS 2020; 8(2): 2922-2924

(C) 2020 IJCS

Received: 10-01-2020

Accepted: 12-02-2020

Deepthi KC

Department of Microbiology,

PJTSAU, Hyderabad,

Telangana, India
Corresponding Author:

Deepthi KC

Department of Microbiology,

PJTSAU, Hyderabad,

Telangana, India

\section{Antiviral properties of medicinal plants of human diseases}

\section{Deepthi KC}

DOI: https://doi.org/10.22271/chemi.2020.v8.i2as.9193

Abstract

The term Antiviral agents are inhibiting their capability to reproduce the virus. The present review was focused on medicinal plants which are used in the treatment of viral diseases such as Herpes simplex virus, Influenza, Measles, Hepatitis-B virus and Dengue virus. Traditional medicinal plants recognized as alternate source for viral diseases. Some of the whole plant parts and extractions have specific antiviral properties to cure the diseases. In this review, 22 plant species of different families have antiviral properties. The present study focused on different plant species to treat different viral diseases.

Keywords: Medicinal plants, antiviral, hepatitis-B, influenza, dengue virus

\section{Introduction}

Plants are one of the most important sources of the medicines. The medicinal plants are extensively utilized throughout the world in two distinct areas of health management i.e., traditional system of medicine and modern system of medicine. The use of medicinal plants over the centuries has become an important part of daily life. Approximately 3000 plant species are known to have medicinal properties in India (Poornima et al., 2010) ${ }^{[12]}$. According to Huxley (1984) ${ }^{[10]}$, noted that around 6000 plant species only 2500 plant species have medicinal values in India. Our traditional systems of medicines utilized herbs for treatment of various health disorders. The World Health Organization (WHO) estimated around 80 percent of the world population rely mainly on traditional medicines (Akerele., 1992) ${ }^{[1]}$.

Plants contain many medicinal values for treating various diseases based on their infectious nature. The curative properties of medicinal plants are due to the presence of complex chemical substances such as glycosides, steroids, saponins, tannins, alkaloids, terpenoids, lignans, and many other active components (Jassim S.A.A. and Naji M.A. (2003) ${ }^{[8]}$; Ojo et al., 2009) ${ }^{[11]}$, which are present as secondary plant metabolites. Different workers studied the uses of medicinal plants contain antiviral properties for controlling human diseases (Pushpa et al., 2013, Gupta et al., 2015, Siddiqui et al., 2017, Semenya et al., 2018, Anand et al., 2019) [13, 7 , $16,17,6]$. The present literature reveals the detailed information of various human viruses on antiviral activity. Hence it is proved that major medicinal plants play a key role to control the diseases like Herpes simplex virus, Hepatitis-B, Influenza, Measles, Dengue virus.

\section{Herpes Simplex Virus}

Herpes simplex virus belongs to the family Herpes viridae. Herpes simplex virus type-1 mainly transmits through oral contact and causes infection around the mouth i.e., cold sores, whereas Herpes simplex virus type- 2 transmits through genital herpes. Its incubation period is between 2 to 12 days. Several medicinal plants like Azadiracta indica, Carica papaya, Punica granatum etc. were screened to detect their antiviral activity (Jadhav et al,. 2012) ${ }^{[9]}$. Some of the medicinal plants which treats Herpes simplex virus as follows

Caesalpinia pulcherrima (L.) Sw. (Fabaceae):

The whole plant including stem, leaf, flower, and fruit and seed possess antiviral activity which is derived from the quercetin (flavonoid).

Adansonia digitata L. (Malvaceae):

The extract of the leaf contains antiviral properties.

Camellia sinensis (L.) Kuntze (Theaceae): 
The leaves contains a polyphenolic compounds Green Tea Catechins (GTCs) contains antiviral properties.

Ardisia elliptica Thunb. (Myrsinaceae):

Hot water extract of Ardisia squamulosa was found effective against antiviral properties.

Agrimonia pilosa Ledeb. (Rosaceae):

Stems and leaves contain antiviral properties.

\section{Influenza}

Influenza or the $f l u$ is an acute infectious disease of respiratory system which occurs in sporadic, epidemic and pandemic form. This is characterized by fever, headache, malaise and general pains. Influenza is caused by Orthomyxovirus group which are pleomorphic in nature. This virus enters through respiratory tract. Several Medicinal plants like Allium fistulosum, Sambucus nigra, Ocimum basilicum were studied to control influenza disease which acts as antiviral herbs (Anuradha J. 2018) ${ }^{[5]}$. Some of the medicinal plants which treats Influenza Virus as follows:

Brassica campestris Linn (Cruciferae):

Powdered seeds used for influenza and cold.

Camellia sinensis (Linn.) O. Kuntze. (Theaceae):

The green tea contains active compound epigallocatechin gallate and aflavin digallate from green tea inhibited the influenza.

Citrus limon (Linn.) Burm.f. (Rutaceae):

Fruit used for inhibiting influenza

Citrus paradisi Macf. (Rutaceae):

Fruits are used for developing resistance against influenza.

Melaleuca leucadendron Linn (Myrtaceae):

Oil is used as an expectorant in chronic laryngitis and bronchitis and used for influenza.

Moringa pterygosperma Gaertn (Moringaceae):

Leaves are used for developing resistance against influenza.

Ocimum sanctum Linn (Lamiaceae):

Leaf and seeds are used against influenza.

Peganum harmala Linn. (Zygophyllaceae):

The extraction of seeds exhibited significant antiviral activity against influenza.

Ranunculus trichophyllus Chaix (Ranunculaceae):

Extraction of the dry root is given for cough and influenza.

Reissantia grahamii (Wight) Ding Hou. (Celastraceae):

Roots are used for the treatment of influenza.

Sambucus nigra Linn (Caprifoliaceae):

Plant berries are used against influenza virus.

Verbascum thapsus Linn (Scrophulariaceae):

The flower extract showed antiviral activity against influenza.

\section{Hepatitis-B virus}

The hepatitis $\mathrm{B}$ virus belongs to the family Hepadnaviridae which causes hepatitis $\mathrm{B}$ in humans. Hepatitis B is a viral infection that attacks the liver and can cause both acute and chronic disease. The incubation period of the hepatitis B virus is 75 days on average, but can vary from 30 to 180 days and it is transmitted through blood and infected bodily fluids as well as through saliva, menstrual, vaginal, and seminal fluids. Some of the medicinal plants were reported to cure Hepatitis-B viruses (Pushpa et al., 2013) ${ }^{[13]}$. Some of the medicinal plants treated to Hepatitis B Virus are as follows:

Eclipta prostrata (L.) L. (Asteraceae):

The whole plant is used against hepatitis B-virus.

Isatis tinctoria Linn. (Crucifere):

Leaves and roots are effective in treating hepatitis B.

Phyllanthus niruri Linn. (Euphorbiaceae):
The plant is reported to show antiviral activity against hepatitis B virus.

Silybum marianum (L.) Gaertn. (Asteraceae):

Silymarin has been used to treat patients hepatitis B virus

\section{Measles}

Measles is a highly infectious illness acute in nature which belongs to the family Paramyxovirus and sub family Morbillivirus. It is characterized by a high fever (almost $105^{\circ} \mathrm{F}$ ), cough, malaise, and conjunctivitis (Strebel et al., 2008) ${ }^{[15]}$ and its incubation period is 14 days (American Academy of Pediatrics; 2009) ${ }^{[4]}$. It can spread through the air from respiratory droplets and small aerosol particles. An infected person can release the virus into the air when they cough or sneeze. Some of the medicinal plants like Artemisia dubia, Cinnamomum camphora, Elephantopus scaber, Polycarpon prostratum etc. were studied against measles (Gupta et al., 2015) ${ }^{[7]}$. Some of the medicinal plants which treats measles as follows:

Acacia torta (Roxb.) Craib (Mimosaceae):

Various plant parts are used measles.

Azadirachta indica A. Juss (Meliaceae):

Leaf and bark contains antiviral property and it is effective against measles.

Bupleurum flacutum Linn. (Apiaceae):

$5 \mu \mathrm{m}$ of concentrated Saikosaponin-d inactivates measles virus at room temperature.

Cajanus cajan (Linn.) Millsp (Fabaceae):

Leaves are used in treating measles disease.

Clerodendrum phlomidis Linn.f. (Verbenaceae):

Plant parts are used for measles.

Dolichos biflorus Linn (Fabaceae):

Whole plant is used for treating measles

Lithospermum officinanle Linn. (Boraginaceae):

A decoction of roots and twigs is given in the form of syrup for treating measles.

\section{Dengue virus}

Dengue fever is also known as "break bone fever", which belongs to the family flaviviridae. It is transmitted via infected blood transfusions, plasma and platelets after completion of its incubation period of 5-8 days sudden fever will develop with severe headache and pain in the muscles and joints. Rothan (2014) ${ }^{[14]}$ studied Vernonia cinerea leaves of methanolic extract contains inhibitory activity against dengue virus. Some of the medicinal plants which treats dengue virus as follows:

Andrographis paniculata (Burm.f.) Nees (Acanthaceae):

Leaves contain antiviral properties.

Momordica charantia L. (Cucurbitaceae):

Ethanolic extracts from leaves and stem shows antiviral activity.

Kaempferia parviflora Wall. ex Baker (Zingiberaceae):

Leaves and stem contains antiviral properties.

Azadirachta indica A. Juss. (Meliaceae):

Leaves contains antiviral properties.

\section{Conclusion}

In conclusion a wide variety species of medicinal plants which are available with their active compounds contains antiviral properties which deserve more attention because still some active compounds which are present in medicinal plants are unknown. There are few plant species viz., Andrographis paniculata, Momordica charantia, Cajanus cajan, Azadirachta indica, Eclipta prostrata, Ocimum sanctum, 
Camellia sinensis, etc. which controls the antiviral diseases against Hepatitis-B, Herpes simplex virus, Influenza, Measles, Dengue fever, etc. with their medicinal values naturally. There are certain significant attempts were made already revealing antiviral properties of medicinal plants. Therefore further studies should be carried out by extracting their active compounds which can be processed like novel drugs individually which may lead to discovery of effective drugs to control these viral diseases.

\section{References}

1. Akerele O. WHO guidelines for assessment of herbal medicines. Fitoterapoa. 1992; 63:99-118.

2. American Academy of Pediatrics. Measles. In: Pickering LK, Baker CJ, Kimberlin DW, Long

3. SS, editors.: Red book: report of the committee on infectious diseases. 28th edition. Elk

4. Grove Village, IL: American Academy of Pediatrics 2009, 444-6.

5. Anuradha J, Kasim Muhtari, Henna Lone, Sandeep Tripathi, Sanjeevi R. Potentials of Herbs on the Rescue of Influenza Prevention and Control. J. Chem. \& Cheml. Sci. 2018; 8(5):898-903.

6. Anand Uttpal, Nadia Jacobo-Herrera, Ammar Altemimi, Naoufal Lakhssassi. A Comprehensive Review on Medicinal Plants as Antimicrobial Therapeutics: Potential Avenues of Biocompatible Drug Discovery. Metabolites. 2019; 9:258.

7. Gupta Sharmistha, Mithun Mukherjee, Some Useful. Medicinal Plants Used against Measles from West Bengal. IOSR Journal of Pharmacy. 2015; 5(2)13-19.

8. Jassim SAA, Naji MA. Journal of Applied Microbiology. 2003; 95(3):412-27.

9. Jadhav P, Kapoor N, Thomas B, Lal H, Kshirsagar N. Antiviral potential of selected Indian medicinal (ayurvedic) plants against herpes simplex virus 1 and 2 . N Am J Med Sci. 2012; 4(12):641-7.

10. Huxley: Green inheritance: The world wildlife fund book of India. (Collins/Harvel London), 1984.

11. Ojo OO, Oluyege JO, Famurewa O. African Journal of Plant Science. 2009; 3(7):157-9.

12. Prakasha HM, Krishnappa M, Krishnamurthy YL, Poornima SV. Folk medicine of NR Pura Taluk in chikamaglur district of Karnataka. Indian journal of traditional knowledge. 2010; 9(1):55-60.

13. Pushpa Ruwali, Rai Nishant, Kumar Navin, Gautam Pankaj. Antiviral potential of medicinal plants: an overview. Int. Res. J Pharm, 2013; 4(6).

14. Rothan HA, Zulqarnain M, Ammar YA, Tan EC, Rahman NA, Yusof R. Screening of antiviral activities in medicinal plants extracts against dengue virus using dengue NS2B-NS3 protease assay. Trop. Biomed. 2014; 31(2):286-96.

15. Strebel P, Papania MJ, Dayan GH, Halsey NA. Measles Vaccine. In: Plotkin SA, Orenstein WA, Offit PA, editors. Vaccines 5th edition. Philadelphia: WB Saunders, 2008, 353-98.

16. Siddiqui Manzer H, Saud A Alamri, Mohamed H, AlWhaibi, Zahid Hussain, Hayssam M Ali, Mohamed E ElZaidy. A mini-review of anti-hepatitis B virus activity of medicinal plants, Biotechnology \& Biotechnological Equipment. 2017; 31(1):9-15.

17. Semenya Sebua Silas, Alfred Maroyi. Data on medicinal plants used to treat respiratory infections and related symptoms in South Africa. Data in Brief. 2018; 21:419423. 